\title{
To Be His Own Savior-An Analysis on Caulfield's Self-Salvation Based on Archetypal Approach
}

\author{
HE Wei \\ Sichuan University of Arts and Science, Dazhou, China
}

\begin{abstract}
Caulfield, a hero of the novel The Catcher in the Rye by J. D. Salinger (2008), is caught in the adolescence transition between the childhood and the adulthood. However, he is physically prepared but mentally unprepared for this period. Therefore, he tries to look for his savior to guide him out of this dilemma, which turns out to be a failure. After suffering the disillusionment of finding his savior, Caulfield wants to become other children's savior in the rye.This thesis tries to analyze Holden's action of being other children's savior based on archetypal approach. His dream of being others' savior equals him to Jesus Christ in modern times and the rye equals to Garden of Eden in modern times. He dreams like Jesus Christ to protect children like his sister suffering from his fate.
\end{abstract}

Keywords: Caulfield, archetypal approach, modern Jesus Christ, modern Garden of Eden

Caulfield, a hero of the novel The Catcher in the Rye, is caught in the adolescence transition between the childhood and the adulthood, a period need not just be physically prepared but more important be mentally prepared. Thus, Caulfield finds himself physically prepared but mentally unprepared for getting into adulthood. Therefore, he is desperately in need of a savior to help him out of his dilemma.

Caulfield is referred to be Christ in the sense of his virtue and his tragic fate. Just as Jesus Christ is the incarnation of universal love, devotion, and perseverance, so Caulfield is the personification of many similar virtues. Jesus comes down from the heaven on the earth in order to redeem the sinful mankind and at the end he accomplishes his tasks through being crucified on the cross, while Caulfield is willing to be the rescuing children from falling in the rye.

\section{Suffering the Disillusionment in the Search of His Savior}

Caught in the adolescence transition between the childhood and the adulthood, Caulfield tries to search one to guide him out of his dilemma, from his roommates Stardlater and Ackley to his father, brother D. B., and teacher Antolini. However, none of them can provide the help he needs.

Caulfield's parents are unqualified during his growing-up process. Except some financial support, Caulfield cannot get any useful suggestion from his parents. Then Caulfield turns to his older brother D. B. He has taken care of Caulfield since he was young and attended Allie's funeral when Caulfield stayed at the hospital for hurting his hand. And he often goes to see Caulfield every weekend and drives him home. The sibling relationship between them becomes the main emotional support of Caulfield and his older brother serves "as surrogate parents, acting as caretakers, teachers, playmates and confidants" (Rice, 1990, p. 441). But

HE Wei, lecturer, M.A., Foreign Language Department, Sichuan University of Arts and Science, Dazhou, China. 
after Allie's death, D. B. deserts Caulfield and abandons his true dream, which makes Caulfield label his brother a "prostitute" for trading his talent for money (Salinger, 2008, p. 217). As a result, D. B. makes himself "As emotional remote from him [Holden] as is his father" (Rowe, 1991, p. 89). Then Caulfield has to seek others who can supplant his parents or older brother.

The next person Caulfield turns to is his former teacher, Mr. Antolini from Elkton Hills, "I'd been there quite a few times, because after I left Elkton Hills Mr. Antolini came up to our house for dinner quite frequently to find out how I was getting along" (Salinger, 2008, p. 411). Caulfield likes Mr. Antolini very much, especially when Mr. Antolini called Caulfield to tell D. B. not to go to Hollywood. In addition, Mr. Antolini is a pretty young guy, not much older than his brother D. B., and Caulfield even thinks that Mr. Antolini is sort of like D. B. (Salinger, 2008, p. 411). After D. B. drifts away from Caulfield in emotion, Mr. Antolini is the one Caulfield can turn to "after all the other fathers of his world have failed him, including his real father" (Baumban, 1990, p. 56). However, his action of showing his care is understood as homosexual intimacy by Caulfield and then his image as one father figure shatters into pieces. The next comforter appearing in Caulfield's mind is Carl Luce, his former sex Counselor.

Carl Luce is Caulfield's Student Advisor at Whooton. And he is a college student at Columbia when Caulfield is wandering in the New York City. For Caulfield, he is more experienced than him. Badly in need of a savior to guide him out of his dilemma, Caulfield asks Carl to meet him as the Wicker Bar. To his disappointment, Carl refuses to answer his questions sharply. Caulfield seems to be too immature for Carl to benefit from his advice. That is why he keeps on asking Caulfield when he will grow up. Luce behaves like the older brother who feels his brother is too young to share his experience. Afterwards, Caulfield is deserted by him at the bar without benefiting from any mentoring or guidance.

Throughout the novel, Caulfield is badly in need of a savior, but only to find a world lacking of older male role models. He is struggling throughout the book for his inability of "invest his trust in anyone who is not image of innocence" (Bloom, 1996, p. 6).

\section{Modern "Jesus Christ"}

All the kids kept trying to grab for the gold ring, and so was Phoebe, and I was sort of afraid she'd fall off the goddam horse, but I didn't say anything or do anything. The thing with kids is, if they want to grab for the gold ring, you have to let them do it, and not say anything.

- The Catcher in the Rye

The paragraph above shows that although Caulfield has accepted the inevitability of growing up while watching the children try to get the golden ring, he is still worried about their potential falling - entering into the adult world. Thus, he fancies being their protector to keep them from falling into the adult world, being young forever.

Caulfield's desire to be those children's savior, modern Jesus Christ, has a lot to do with Western traditional belief-Christianity, the ideology influencing westerners' lives in almost every aspect. It is preached that God was the creator of the world. When the world became a realm of darkness alien from God's original purpose, God sent his son - Jesus Christ — on earth to save the world from its darkness. Jesus Christ performed many miracles to make the public believe that he was their savior. And the story of Jesus' encounter with the Samaritan provided the setting for this saying. Jesus spoke to the Samaritan woman outside the town of Sychar, just after their meeting, this woman returned to town and announced his arrival to the public, "Come see a man 
who told me all that I ever did. Could this be the Christ?" (Koester, 1990, p. 665). The Samaritan asked Jesus Christ to stay with them to figure out his true identity. Jesus stayed as this woman required. During Jesus' visit of the Samaritan, he demonstrated many good deeds and even some miracles to make them believe in him, acclaiming him "the Savior of the world" (Craig, 1990, p. 2). Jesus Christ served as the bridge between God and Human beings and he made them believe that the faith in God was the only way to be saved. When Samaritans acclaimed Jesus as their savior, they believed that he would save them from the darkness. In other words, they believed in the Western tradition belief in salvation.

Realizing his alienation from the people around and the society, Caulfield finds his savior is nowhere in the real world. As a teenager living in the 1950s, a period after the two world wars, Caulfield lives in a world where "young males living with the absence of fathers and mentors" (Bly, 1996, p. 180). The two world wars made that generation rootless and they did not know what they should use to live, let along being the model of the younger generation. Frustrated by the unsuccessful attempt of searching a savior, Caulfield does not believe that he could find a Jesus-like figure in the real world as his ancestor. Keenly aware of the awkward situation of himself, Caulfield turns his eyes to the children like his younger sister Phoebe with the hope of being their savior to shelter them from the corruption of the adult world.

In Gwynn and Blotner's mind, Caulfield is a saintly Christian person, "Jesus and Caulfield truly love their neighbors, especially the poor in goods, appearance, and spirit" (1958, p. 56). Knowing being kicked out by Pencey Prep, Caulfield does not cry or do other things to attract others' attention, but the first thing occurs to his mind is to say good-bye to old Spencer, his history teacher who always educates Caulfield in a way that Caulfield dislikes. Caulfield goes to see him in a crazy cold day and listens to his lecture for hours which nearly drives him crazy, but he refrains himself and shows his respect to this old man. And his roommate Stradlater, a sex bastard, is so self-centered and does not show the normal concern to Caulfield, and he even asks Caulfield to write a composition for him after knowing Caulfield's being kicked out of school. However, Caulfield does not complain anything and tries his best to achieve this task in a depressed mood like Jesus conveying the love of God to everyone equally including his enemy, even when he suffers a lot for this. Later, he takes some money to New York City for consolation. During his wandering, he happens to meet two nuns, though he does not have much money, he still gives a generous contribution to them initially. With a hope that those money will do some contribution to those who need it, Caulfield is willing to spare some money to those two nuns and feels sorry for just giving ten bucks, "After they left, I started getting sorry that I'd only given them ten bucks for their collection" (Salinger, 2008, p. 337).

Just like Jesus distributing his mercy to people on earth, Caulfield gives his love to people around. But what frustrated Caulfield is that there is no Jesus-like figure to offer protection to those cute children like his lovely younger sister Phoebe. She lives with a busy father and a mother obsessed with her own sadness. And he happens to meet one family in New York City. When the boy walks in the street next curb, the parents do not realize their boy is in danger. This experience makes Caulfield know there is no ideal place for the children to live in the real world.

\section{Modern "Eden of Garden"}

For Caulfield, the place for children should be free from all the evils, like The Garden of Eden for our ancestors Adam and Eve. The Garden of Eden is described in the Book of Genesis as the place where the first man Adam and his wife lived after being created by God. Literally, the Bible speaks about a garden in Eden. In 
the Holy Bible, the Garden of Eden is the place that our ancestors get from God as his blessing. It is a place full of all the things and free from all kind of anxiety, no suffering and no pain. Our ancestors Adam and Even enjoy their lives to the fullest extent, free from all the fetters. Their happy life lasts till being driven from the Garden of Eden for their desire to be experienced.

It is Caulfield's obsession with children's world that drives him to find a place where time is out of function; everyone can keep from maturity, being young and innocent forever. In other words, Caulfield is dreaming of an Edenic world where he and other children can live care-free.

Then can Caulfield find the Garden of Eden in real world? Two-days' wandering in New York City makes Caulfield believe there is no place where children can avoid being polluted by the adult world. He tried many times to erase the profanity on the school and museum walls. The thought of corruption on school affects Caulfield so severely that he nearly loses his mind,

It drove me damn near crazy. I thought how Phoebe and all the other little kids would see it, and how they'd wonder what the hell it meant, and then finally some dirty kid would tell them-all cockeyed, naturally — what it meant, and how they'd all think about it and maybe even worry about it for a couple of days. I kept wanting to kill whoever'd written it. I figured it was some pervert bum that's sneaked into the school late at night to take a leak or something and then wrote it in the wall. I kept picturing myself catching his at it, and how I'd smash his head on the stone steps till he was good and goddam dead and bloody (Salinger, 2008, pp. 431-432).

Caulfield nearly flies into rage when seeing all the dirty words threat the innocence he tries to protect. What is more, he finds there is no ending of this action. No matter how many times he erases the profanity, he can still find it in other places, like the walls of the museum. Finally, Caulfield has to admit that there is no Garden of Eden in the real world any more,

That's the whole trouble. You can't even find a place that's nice and peaceful, because there is not any. You may think there is, but once you get there, when you're not looking, somebody'll sneak up and write "Fuck you" right under your nose. (Salinger, 2008, p. 434)

Failing to find any nice and peaceful place in real world, Caulfield is stricken by Robert Burn's poem "If a body catch a body comin' through the rye" (2008, p. 409). Caulfield pictures a big field of rye far away from the real world where only children live and play; meanwhile, Caulfield himself can perform his duty of being their savior who catches every child before their falling.

The field of rye is the Garden of Eden where Caulfield is the king and he even sets up the rules for sex in his own kingdom. "Sex is something I really don't understand to hot. You never know where the hell you are. I keep making up these sex rules for myself, and then I break them right away" (Salinger, 2008, p. 283). And he admits to his younger sister that to be a catcher in the rye is the only thing he wants to do, for the rye field is a place where he can preserve the innocence forever. Meanwhile, the rye is located in a place far away from adults and too high for the children to see beyond the borders of their childhood. Being the catcher of the rye, Caulfield can protect those children from suffering the disillusionment accompanying in the process of growing up.

\section{Conclusion}

On the threshold of adulthood, Caulfield needs a person to guide him into adulthood. However, he finds himself physically prepared but mentally unprepared. Thus, he turns to his parents, brother, and teacher for help, which turns out to be a total failure. After the disillusionment of finding his own savior, he dreams 
to be modern Jesus Christ in modern Garden of Eden to protect those children from being polluted by adult world.

\section{References}

Baumbach, J. (1990). The saint as a young man: A reappraisal of The Cather in the Rye. Modern Language Quarterly, 25(4), 461-472.

Bloom, H. (1996). Introduction. J. D. Salinger's The Catcher in the Rye: Bloom's notes. Broomall, PA: Chelsea House.

Bly, R. (1996). The sibling society. MA: Addison-Wesley Publishing Company.

Craig, R. K. (1990). The savior of the world (John 4: 42). Journal of Blilical Literature, 109(4), 1-14.

Gwynn, F. L., \& Blotner, J. L. (1958). The fiction of J. D. Salinger. Pittsburgh: University of Pittsburgh Press.

Rice, P. F. (1990). The adolescent: Development, relationship, and culture (6th ed.). Boston: Allyn and Bacon.

Rowe, J. (1991). Caulfield and American protest. In J. Salzmann (Ed.), New essays on The Catcher in the Rye. Cambridge: Cambridge University Press.

Salinger, J. D. (2008). The catcher in the rye. Nanjing: Yiling Press. 